\title{
Novel use of trypan blue in ocular surface staining: redefining implications for this vital dye
}

\author{
Nova aplicação do azul de tripano para \\ superficie ocular: redefinindo corantes vitais
}

Renato Ambrósio Jr. ${ }^{1,2,5}$, Habeeb Ahmad $^{3}$, Diogo Caldas ${ }^{2}$, Ana Laura Caiado Canedo ${ }^{1,2}$, Bruno Valbon ${ }^{1,2}$, Frederico Procopio Guerra ${ }^{1,2,4}$, Acácio Alves de Souza Lima ${ }^{5}$

\begin{abstract}
Different applications of trypan blue (TB) for intraocular surgery have been reported, with very high levels of safety and efficacy. We describe the use of TB as an alternative vital dye for staining the ocular surface to assess the integrity of superficial cell layers of the cornea and the surface environment. This facilitates the diagnosis of various ocular surface disorders, including screening for dry eye disease (DED) among refractive and cataract patients. TB staining properties are different from fluorescein and both are stable in a solution, so that a double staining technique is introduced.
\end{abstract}

Keywords: Eye diseases/surgery; Ophthalmologic surgical procedures; Trypan blue/diagnostic use; Staining and labeling/methods; Case reports

\section{ResUMo}

Diferentes aplicações do azul de tripano (AT) foram descritas para cirurgia intraocular, com elevados patamares de eficácia e segurança. Neste relato, é descrito a aplicação do AT como corante vital para superfíce ocular, de modo a estudar a integridade das células da superfície corneana e conjuntival na superfície ocular. Tal abordagem permite um diagnóstico mais sensível de desordens da superfície ocular, destacando-se disfunção lacrimal ou síndrome do olho seco. O AT tem propriedades distintas da fluoresceína, com a qual se mantém estável em solução permitindo a técnica de coloração dupla que é introduzida.

Descritores: Oftalmopatias/cirurgia; Procedimentos cirúrgicos oftalmológicos; Azul tripano/uso diagnóstico; Coloração e rotulagem/métodos; Relatos de casos

'Instituto de Olhos Renato Ambrósio - Rio de Janeiro (RJ), Brazil;

${ }^{2}$ Corneal Tomography and Biomechanics Study Group - Rio de Janeiro (RJ), Brazil;

${ }^{3}$ Doheny Eye Institute - Los Angeles, California - USA;

${ }^{4}$ Price Vision Group - Indianapolis - USA;

${ }^{5}$ Universidade Federal de São Paulo - (UNIFESP) - São Paulo (SP), Brazil

Interest conflitct - None

Recebido para publicação em: 10/10/2011 - Aceito para publicação em 29/11/2011

Rev Bras Oftalmol. 2011; 70 (6): 408-10 

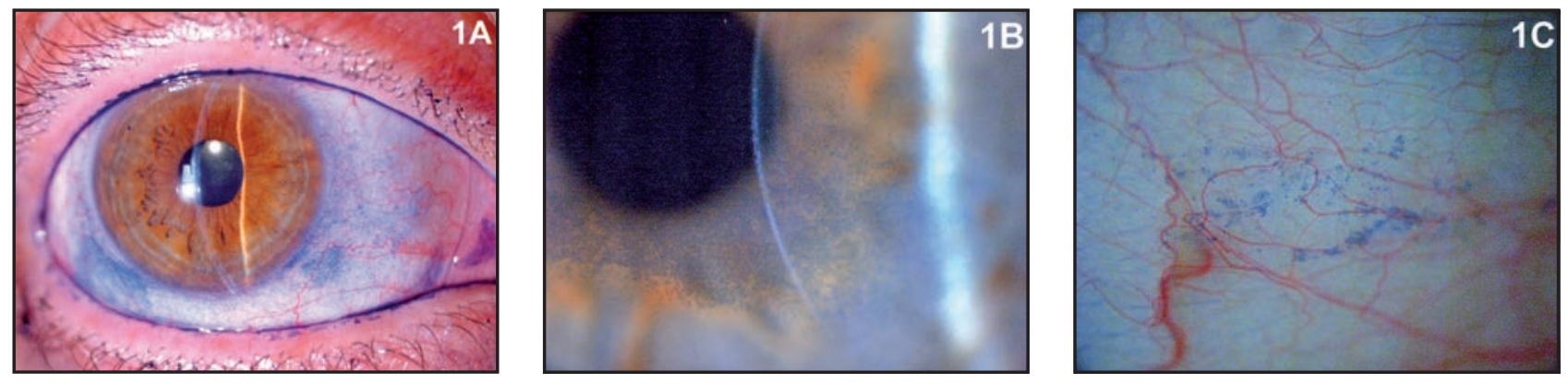

Figure 1A: Trypan blue staining of dry eye patient with Sjogrens Syndrome; 1B - Staining of LASIK induced neurotrophic epitheliopathy(LINE); 1C - Staining of conjunctiva in a patient with contact lens intolerance who suffered dry eye symptoms
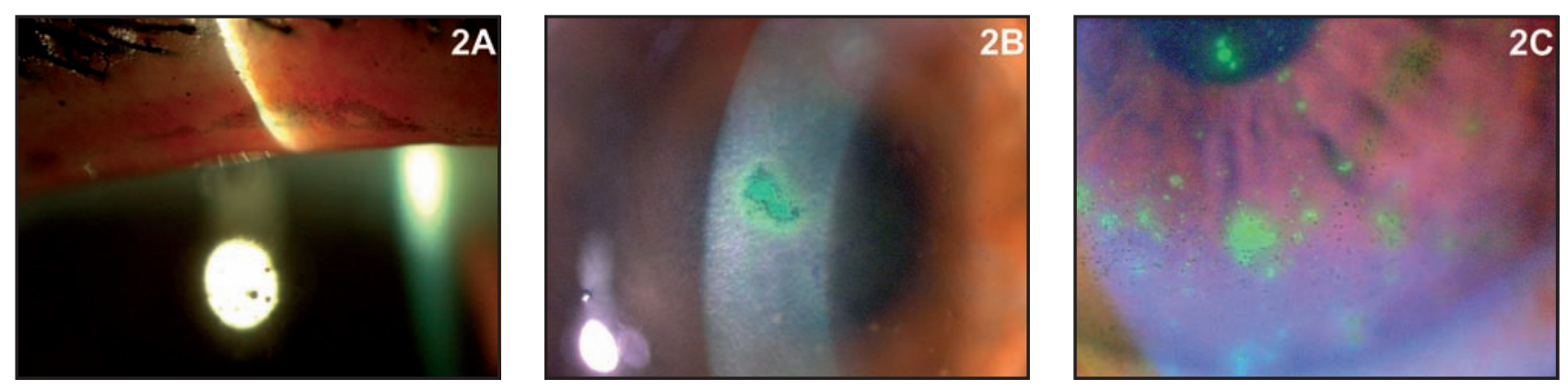

Figure 2A: Staining of the lid margin with trypan blue; $2 \mathrm{~B}$ - Double staining of a recurrent corneal erosion with TB dye and fluorescein; $2 \mathrm{C}$ - Double staining in a patient with epidermic keratoconjunctivitis

\section{INTRODUCTION}

$\mathbf{U}$ biquitous in ophthalmology, vital dyes that stain living tissues including trypan blue, fluorescein, rose bengal, indocyanine green and lissamine green have all facilitated diagnostic and surgical techniques. Trypan blue (TB), an anionic hydrophilic azo dye, is in wide use particularly for staining the capsule during cataract surgery and aiding vitreoretinal surgery ${ }^{(1)}$.

TB dye was first introduced in cataract surgery by Melles $^{(2)}$, and was advocated for all cataract cases in Brasil by Dr. Carlos G. Figueiredo in 2000. Our group adopted this approach in cataract surgery, and it was incidentally noted that TB dye would stain conjunctival and corneal surfaces, particularly in those with poor ocular surfaces. Despite having several dyes that stain ocular surface tissues preferentially, a poor ocular surface can be a diagnostic challenge since symptoms are not always associated with clinical findings ${ }^{(3)}$.

A poor ocular surface is the leading cause of dissatisfaction after LASIK and cataract surgery ${ }^{(4)}$. We present a case series evaluating trypan blue's ability to stain the ocular surface.

\section{Methods}

A cohort of seven patients with known ocular surface disorders were included in this case series. Informed consent was obtained, and the study was in accordance with the Declaration of Helsinki tenets. TB dye used was obtained from Ophthalmos pharmaceuticals (São Paulo, Brasil) at a concentration of $1 \%$. Patients had the dye instilled in their conjunctival cul-de sac and were examined under the slit lamp using red-free or Amber UV cut free filters. Ocular surface staining was observed and photographed. A combination solution consisting of fluorescein and trypan blue $1 \%$ (50/50 mixture) was also obtained from ophthalmos and used in select patients.

\section{Results}

Our series revealed no significant ocular irritation on exam and elicited no complaints with instillation of TB dye. In figure $1 \mathrm{~A}$, a patient with poor ocular surface and Sjogrens syndrome, TB dye demonstrated staining of the cornea and conjunctiva. TB dye also revealed fine staining of a poor ocular surface in a LASIK induced neurotrophic 
epitheliopathy (line), figure $1 \mathrm{~B}$, and in a case of contact lens intolerance with dry eyes, figure $1 \mathrm{C}$. TB dye was also able to stain the everted lids well, figure $2 \mathrm{~A}$, particularly the marginal conjunctival epithelium. We also applied a mixture of both trypan blue $1 \%$ and fluorescein in two patients. Figure 2B illustrates a recurrent corneal erosion in lattice dystrophy exhibiting well-defined staining of the edges with TB dye, and fluorescein staining of the bare stroma. This combination solution revealed two distinct staining patterns delineating superficial punctate keratitis very well in a patient with epidermic keratoconjunctivitis, figure $2 \mathrm{C}$.

\section{Discussion}

Vital dye staining of the ocular surface was first described in 1882 by Pflüger when sodium fluorescein allowed visualization of an epithelial defect ${ }^{(5)}$. Dyes have since played a critical role in ocular surface grading. Trypan blue has many applications including use in cataract surgery, endothelial keratoplasty, and vitreoretinal surgery. However, the study of TB dye for the ocular surface has been neglected since the original article by Norn in $1967^{(6)}$.

Trypan blue has many important applications in intraocular surgery and is very popular for facilitating capsulorrhexis ${ }^{(2,7)}$. Our research demonstrates that TB dye is also efficient at staining conjunctival and corneal surfaces in those with poor ocular surfaces. Of particular interest, is TB dye's complementary staining pattern in a double solution with fluorescein. This solution has broad implications in cataract and refractive surgery, dry eye management, diagnosing corneal herpetic disease, and aiding ocular surface surgery. Trypan blue presents an ideal and promising adjunct dye for the ocular surface given its wide availability, cost and proven safety profile. Further studies evaluating the sensitivity of TB staining of the ocular surface as well as correlating its findings with severity of symptoms are required.

\section{RefERENCES}

1. Rodrigues EB, Costa EF, Penha FM, Melo GB, Bottós J, Dib $\mathrm{E}$, et al. The use of vital dyes in ocular surgery. Surv Ophthalmol. 2009;54(5):576-617.

2. Melles GR, de Waard PW, Pameyer JH, Houdijn Beekhuis W. Trypan blue capsule staining to visualize the capsulorhexis in cataract surgery. J Cataract Refract Surg. 1999;25(1):7-9.

3. Machado LM, Castro RS, Fontes BM. Staining patters in dry eye syndrome: rose bengal versus lissamine green. Cornea. 2009;28(7):732-4.

4. Ambrósio R Jr, Tervo T, Wilson SE. LASIK-associated dry eye and neurotrophic epitheliopathy: pathophysiology and strategies for prevention and treatment. J Refract Surg. 2008;24(4):396-407.

5. Pflüger. Zur Ernährung der cornea. Klin Monatsbl Augenheilkd. 1882;20:69-81.

6. Norn MS. Trypan blue. Vital staining of cornea and conjunctiva. Acta Ophthalmol (Copenh). 1967;45(3):380-9.

7. Marques FF, Marques DM, Osher RH. New technique to demonstrate corneal magnification using trypan blue in cataract surgery. Rev Bras Oftalmol. 2011;70(4):235-7.

\author{
Corresponding author: \\ Renato Ambrósio Jr, MD, PhD \\ Rua Conde de Bonfim, $n^{\circ}$ 211/712 - Tijuca \\ CEP 20520-050 - Rio de Janeiro (RJ), Brazil \\ e-mail: renatoambrosiojr@terra.com.br \\ (Dr. Ambrósio is a consultant for Oculus)
}

** Awarded 2010 American Society of Cataract and Refractive Surgery (ASCRS) Film Festival Award ** and at the 2010 Alcon Film Festival at International Meeting of the Brazilian Societies of Cataract and Refractive Surgery (BRASCRS) 